๑ Laboratorium: журнал социальных исследований. 2021. 13(3):196-199

DOI: $10.25285 / 2078-1938-2021-13-3-196-199$

\title{
Анна Желнина
}

Jill L. Grant, Alan Walks, and Howard Ramos, eds. Changing Neighbourhoods: Social and Spatial Polarization in Canadian Cities. Vancouver: UBC Press, 2020. 348 pp. ISBN 9780774862028.

Анна Желнина, Хельсинский университет. Адрес для переписки: University of Helsinki, P.0. Box 4, Yliopistonkatu 3, 00014 Helsinki, Finland. anna.zhelnina@helsinki.fi.

Эта книга - результат многолетней инициативы «Партнерство для исследования изменений в городских районах» (Neighborhood Change Research Partnership), которая за тридцать пять лет изучила социально-пространственную сегрегацию в семи канадских городах, чтобы понять, как и почему меняются городские районы.

Изменение городских районов - одна из самых популярных тем в городских исследованиях. Наиболее изученный и очевидный пример районных изменений - джентрификация, процесс, подразумевающий смену одних групп жителей другими (более богатыми, с другим образом жизни и потребления), а также расовые или этнические изменения в составе жителей. В рецензируемой книге исследователей интересуют поляризация и этнокультурные расколы, «еthno-cultural divides» (c. xvii) в больших канадских городах. Редакторы отмечают, что изменения, о которых говорится в книге, носят глобальный характер, но сама книга именно о канадских городах и их специфике. Богатый эмпирический материал и доскональный анализ изменений в семи городах, переведенный на язык практических рекомендаций и политической повестки, - основное достоинство книги; претензий на обогащение или оспаривание теорий городских изменений у авторов нет.

Книга состоит из двенадцати глав, разбитых на три части. Концептуальные основания проекта изложены в трех начальных главах. Первая глава «Неравенство и городские изменения: контекст, концепт и процесс», написанная «интеллектуальными лидерами проекта» (c. xvii) Ларри Борном (Larry Bourne) и Дэвидом Хульчански (David Hulchanski), посвящена определению понятий (что такое neighborhood, о чем говорят демографические изменения на уровне городского района), а также сравнению канадских городских реалий и вписыванию их в международный контекст. В этой же главе дается обзор литературы о «разделенных городах» (divided cities), на которую опирается весь анализ, представленный в книге. Этот подход предполагает, что крупные города развиваются в сторону все большей социально-экономической поляризации, с жестким разделением на более и менее привилегированные группы. Среди последних часто оказываются этнические и расовые меньшинства и иммигранты. Неравенство закрепляется пространственно в результате социального исключения, проблем с доступностью жилья и дискриминации на рынках труда. Продуманная социальная политика, отмечают авторы, может сгладить эти тенденции и предотвратить или сдержать «общественное нездоровье», каковым является поляризация. Как отмечают авторы, поляризация может привести к трудностям в управлении разделенными горо- 
дами, к нетерпимости и социальной напряженности, а также к тому, что популистские политические движения «станут угрозой для демократии» (с. 235).

Доход и иммиграция - два основных способа фиксации неравенства и изменений в канадских городах, используемые в этой книге. Во второй главе «Районное неравенство в канадских городах с 1900 года», написанной Ричардом Харрисом (Richard Harris), мы узнаем, что само слово neighborhood (район) в канадском контексте использовалось именно для обозначения бедных иммигрантских районов. Нарратив о городских изменениях в Канаде напоминает городскую историю США в XX веке, досконально описанную в урбанистической литературе, и развивается вокруг оси «иммиграция - деиндустриализация - субурбанизация - упадок центра». Однако в Канаде гораздо более заметно присутствие государства, благодаря вмешательству которого некоторые социальные проблемы, связанные с этой траекторией городского развития, удалось смягчить. Тем не менее, как отмечает Харрис, в последние десятилетия поляризация все равно нарастает, бедное и дискриминируемое население концентрируется в труднодоступных районах крупных городов. Формирование районов «концентрированной бедности» неизменно вызывает беспокойство исследователей, поскольку, как известно опять же по американской литературе, эта социально-пространственная форма увеличивает груз всех социальных проблем для жителей.

В третьей главе «Использование социальных измерений и типологий районов для описания городских изменений» (авторы Айвен Таунсенд (Ivan Townshend) и Роберт Мурди (Robert Murdie)) представлена типология районов, разработанная авторами проекта для осуществления сравнения между городами. Эта типология районов основана на измерениях переписи населения и включает такие категории, как «социально-смешанный средний класс», «иммигрантская бедность и работники сервис-сектора», «стабильный семейный средний класс» и т. п.

Вторая и самая большая часть книги включает эмпирические главы, написанные разными авторами, о семи включенных в анализ городах: Торонто, Монреале, Ванкувере, Гамильтоне, Галифаксе, Калгари и Виннипеге. Во всех городах исследователи зафиксировали рост экономического неравенства (измеряемого как разрыв между средними доходами в беднейших и самых богатых переписных районах города), хотя в каждом из них этот процесс разворачивается на фоне уникальных местных характеристик. Например, Торонто, самый большой и многообразный город в выборке и в стране, интересен тем, что половина его населения - не уроженцы Канады. Его статус как majority-minority города, то есть города, где большинство населения - это представители меньшинств, особенно актуален в свете растущего неравенства и постоянно ухудшающегося положения этих меньшинств. Джентрификация и вытеснение менее обеспеченных жителей из городского ядра также привели к росту сегрегации по уровню дохода. Любопытное наблюдение из пятой главы книги, посвященной Монреалю, - снижение расслоения англоязычного и франкофонного населения на фоне падения доходов и роста экономического неравенства. Интересен также пример Гамильтона, олицетворения концентрированной бедности среди канадских городов. Автор главы Ричард Харрис отмечает, что «Торонто - не Манхэттен, а Гамильтон - не Бру- 
клин» (с. 169), однако все равно создается впечатление, что эта параллель важна для понимания происходящего в Гамильтоне. Этот бывший индустриальный город сегодня выполняет функции спального пригорода для огромного и дорогого Торонто, становясь все более недоступным для своего изначального населения.

Все «городские» главы книги, помимо обзора траектории городов в XX веке и в последние десятилетия, содержат направленные на смягчение отмеченных негативных тенденций практические рекомендации для выстраивания социальной политики в этих городах. В третьей части книги, состоящей из двух глав, еще раз дается обобщение практической значимости проекта. Правительство Джастина Трюдо, как отмечают редакторы во введении к этой части, запустило множество полезных программ, направленных на контроль неравенства, но все эти меры «привязаны» к конкретным политическим игрокам и могут быть отменены, когда те сойдут со сцены. Как и города, политики в Канаде тоже поляризованы - и это ставит под угрозу социальные программы. В одиннадцатой главе Скотт Грэм (Scott Graham), Стефани Процик (Stephanie Procyk) и Мишлен Лафлеш (Michelynn Laflèche) анализируют состояние канадской социальной политики, направленной на контроль неравенства, и приходят к выводу о ее фрагментированном характере и необходимости большей координации между разными уровнями социальной политики - локальным, провинциальным и федеральным. Они также предлагают конкретные меры в сфере налогообложения, минимальной оплаты труда, жилищного рынка и доступности жилья.

В последней главе три редактора книги подводят сравнительные итоги. Семь изученных городов различаются по размеру, социально-демографическому составу, характеристикам качества и доступности жилья, а также по конфигурации рынков труда. Однако во всех этих разных контекстах наблюдается общий тренд растущее неравенство, джентрификация центральных районов и вытеснение бедного населения из удобных районов с хорошей транспортной доступностью. Авторы отмечают, что, «хотя канадцы гордятся своим более справедливым обществом и менее сегрегированными городами, чем в США, недавние тенденции в сфере экономического неравенства и сегрегации, которые мы показали в наших кейсстади и других работах коллектива, говорят о том, что канадские города начинают походить на своих собратьев, расположенных к югу от границы» (с. 275). Интересно, что расовая сегрегация практически не рассматривается в книге, поскольку, как отмечают редакторы в заключении, не является для канадских городов такой серьезной проблемой, как для американских.

Международные сравнения, за исключением частых сопоставлений с США, появляются в этой книге лишь в первой главе. Опытному читателю работ по городским исследованиям может показаться досадной постоянная апелляция авторов концептуальных глав этой книги к «развитому» миру. Весь «глобальный контекст», в который помещают Канаду авторы, - это три кластера стран: Северная и Западная Европы, а также «англо-американские» страны, в которые включены бывшие и нынешние доминионы Британской империи, включая Ирландию. На первый взгляд, логика понятна: сравнивать нужно сравнимое. Однако литература о «разделенных городах» гораздо шире этого условно «северного» ареала; жаль, что 
рефлексия по этому поводу в книге отсутствует. Единственное постоянно возникающее на протяжении всей книги осмысленное международное сравнение - это сравнение Канады с «южным соседом», США, в котором все противоречия и неравенства оказываются гораздо острее и катастрофичнее.

В первой главе книги приводятся графики, на которых сопоставлены между собой три кластера стран. И по коэффициенту Джини, и по вкладу налоговых сборов в ВВП англосаксонские страны стабильно выглядят хуже европейских (за исключением Ирландии, которая является членом Евросоюза, но все равно включена в англосаксонский кластер, что заставляет задаться вопросом о ценности и смысле такой классификации). Любопытно, что по этим показателям Россия уверенно попала бы в англосаксонский кластер, совсем немного уступая США по уровню экономического неравенства (и опережая Канаду). И хотя авторов этой книги интересуют исключительно канадские города и их сравнение с «южным соседом», российскому читателю может быть полезно, вооружившись понятиями и методами исследования городских неравенств, порассуждать о том, как поляризация и сегрегация могут проявиться и в российских городах. Если у читателя нет специального интереса именно к канадским городам, то наиболее любопытны в книге будут методология измерения и внутринационального сравнения городского неравенства, а также практическая ориентированность в изложении результатов исследования. 